Original Article

\title{
Macrozoobenthos in an altitudinal gradient in North Patagonian Cautín River (Araucanía Region, Chile)
}

\author{
Macrozoobentos em gradiente altitudinal no norte da Patagônia, Rio Cautín \\ ( $38^{\circ} \mathrm{S}$, região da Araucanía, Chile) \\ D. Figueroa ${ }^{\mathrm{a} *}$ (1) and P. De los Rios-Escalante $\mathrm{b}^{\mathrm{b}, \mathrm{c}}$ (D) \\ a Universidad Católica de Temuco, Facultad de Recursos Naturales, Departamento de Ciencias Ambientales, Casilla, Temuco, Chile \\ ' Universidad Católica de Temuco, Facultad de Recursos Naturales, Departamento de Ciencias Biológicas y Químicas, Casilla, Temuco, Chile \\ 'Núcleo de Estudios Ambientales UC Temuco, Casilla, Temuco, Chile
}

\begin{abstract}
The Cautín River is closely related with the economic development of Temuco city, ( $38^{\circ} \mathrm{S}$; Chile). Existing knowledge of the Cautín River is limited to information about its biological characteristics as a reference for the evaluation and assessment of water quality. The object of this study was to develop taxonomic characterisation of the benthic macroinvertebrates along the main course of the Cautín River, and to study the community structure using correlation analysis between community parameters. To carry out this research, the macroinvertebrate community was studied in 10 sampling sites distributed along the main course of the river. The samples were taken in summer (1997 and 2000), when optimal hydrological conditions existed. Analysis of the samples showed that the benthic fauna was composed of 56 taxa, the dominant group being insects with 48 taxa. Three main sectors were recognised in the course of the Cautín River: high, middle and low. Each sector has restricted-distribution species, while other species are widely distributed along the river. These distribution patterns seem to be influenced by dissolved oxygen concentration, temperature, altitudinal distribution and anthropo-cultural activity, present at every sampling site. Finally, this research provides a first approach to the biology of the Cautín River. Further studies could be planned on the basis of this knowledge to investigate water quality indicators based on macroinvertebrate communities.
\end{abstract}

Keywords: altitudinal distribution, human impacts, North Patagonia, stream ecology.

\begin{abstract}
Resumo
O rio Cautín está intimamente relacionado ao desenvolvimento econômico da cidade de Temuco ( $38^{\circ} \mathrm{S}$; Chile). Quanto ao conhecimento total do rio Cautín, existem informações limitadas sobre as características biológicas que podem servir de referência para a avaliação da qualidade da água. Este estudo tem o objetivo de caracterizar os macroinvertebrados bentônicos taxonomicamente ao longo do curso principal do rio Cautín e estudar a estrutura da comunidade usando análise de correlação entre os parâmetros dela. Para realizar esta pesquisa, a comunidade de macroinvertebrados foi estudada em dez locais de estudo distribuídos ao longo do rio principal. As amostras foram coletadas no verão (1997 e 2000), em razão das condições hidrológicas ideais. A análise das amostras mostrou que a fauna bentônica é composta de 56 táxons, sendo o grupo dominante o de insetos com 48 táxons. Na distribuição do principal no curso do rio, três setores são reconhecidos: alto, médio e baixo no rio Cautín. Cada setor possui espécies de distribuição restrita e outro com ampla distribuição ao longo do rio. Esses padrões de distribuição parecem influenciar a concentração de oxigênio dissolvido, a temperatura, a distribuição altitudinal e a atividade antropocultural desenvolvida em todos os locais de amostragem. Finalmente, esta pesquisa fornece uma primeira abordagem biológica do rio Cautín e, de acordo com esses conhecimentos, um estudo posterior pode ser planejado em relação aos indicadores de qualidade da água e com base nas comunidades de macroinvertebrados.
\end{abstract}

Palavras-chave: distribuição altitudinal, impactos humanos, Patagônia norte, ecologia de riachos.

\section{Introduction}

The literature about benthic communities in rivers reveals marked differences due to natural changes in water quality along river courses. These differences may be marked due to human intervention in the surrounding basin, as has been described for other

southern South American rivers (Figueroa et al., 2007; Miserendino et al., 2018). On the basis of this information, the benthic invertebrates reported in water bodies under determined environmental conditions can be used as water quality bioindicators (Hauer \& Lamberti, 2007),

*e-mail: dfiguero@uct.cl

Received: July, 3, 2020 - Accepted: November 17, 2020

This is an Open Access article distributed under the terms of the Creative Commons Attribution License, which permits unrestricted use, distribution, and reproduction in any medium, provided the original work is properly cited. 
mainly considering physical-chemical parameters such as dissolved oxygen, temperature and stream velocity (Allan \& Del Castillo, 2007). A similar situation is reflected in the marked changes in species composition due to the zoning patterns caused by changes in river hydraulics and physical parameters, and by altitudinal gradient (Allan \& Del Castillo, 2007), such as been reported for rivers in south central Chile (Figueroa et al., 2007). The changes in benthic community structure in fluvial systems are explained by factors such as the food diversity available and habitat areas for littoral flora and fauna (Allan \& Del Castillo, 2007). Hauer \& Lamberti (2007) mention that benthic community structure and composition are closely related to the littoral zones of a river, indicating changes in feeding functional groups along its course; they also note hypothetical groups that suggest predictable changes in the structure and function of the benthic communities in fluvial systems according to energy inputs.

Few studies have been carried out in the rivers of Patagonian Chile (Figueroa et al., 2003, 2007, Moya et al., 2009; Fierro et al., 2015; De los RíosEscalante et al., 2020; Barile et al., 2021), with some benthic studies based on stomach contents studies (Vargas et al., 2010; Barile et al., 2021); moreover, these descriptions are based on taxonomic categories rather than species-level identification. The Bíobío river is the only reference fluvial system in Chile for which the benthic and fish communities have been described (Arenas 1995). The only information for the Cautín River consists of preliminary reports on taxonomy and distribution, restricted to some zones of its middle course (Figueroa, 2000; Vega et al., 2020). In the context of this scarcity of information, it would be expected that benthic communities would change along the course of the river due to physical-chemical variations. The object of this study was to develop taxonomic characterisation of the benthic macroinvertebrates along the main course of the Cautín River, and to study the community structure using correlation analysis between community parameters.

\section{Material and Methods}

\subsection{Study area}

The Cautin River is the principal affluent of the Imperial River. It is $174 \mathrm{~km}$ long, and its sedimentary composition makes it a ritron river (Rivera et al., 2004; Fernández et al., 2018; Acuña, 2020). It rises to the south of the Lonquimay River, and draws waters from the Sierra Nevada and Cordillera de las Raíces, which limit the Bíobío Basin (Rivera et al., 2004). Its regime is seasonal, with mean stream velocity of $101 \mathrm{~m}^{3} / \mathrm{s}$ in the higher sector in the Andes and $277 \mathrm{~m}^{3} / \mathrm{s}$ in the middle sector. The maximum stream velocities recorded in winter for the same sites are $160 \mathrm{~m}^{3} / \mathrm{s}$ and $592 \mathrm{~m}^{3} / \mathrm{s}$ respectively (Rivera et al., 2004). The main water inputs into the Cautín River are precipitations and snowmelt brought down by streams that drain the higher part of the sub-basin where snow lies in winter, above approximately 1400 m.a.s.l. The Cautín River sub-basin contains at least 236,000 habitants in the city of Temuco, which is approximately $40 \%$ of the total human population of the Imperial River basin. In this section of the river it receives its main pollution load in the form of waste water from Temuco (Rivera et al., 2004; Fernández et al., 2018; Acuña, 2020).

In terms of natural resources, the Cautín River basin can be divided into two main areas: one in the Andes mountains and the other in the intermediate depression or central valley. The higher zone is characterised by steppe, mountain shrub plant formations and Araucaria and Nothofagus forests. The intermediate depression has a marked degree of anthropogenic intervention through agricultural activities (Rivera et al., 2004; Fernández et al., 2018; Acuña, 2020). The main uses of the Cautín River are associated with towns lying close to the river, predominantly drinking water, irrigation, recreation and discharge of waste water and liquid industrial waste (Rivera et al., 2004; Fernández et al., 2018; Acuña, 2020).

The benthic invertebrate fauna was sampled at ten different sampling sites, considering human intervention, altitude distribution and accessibility. In the high sector: Volcán Lonquimay (Site 1), Malalcahuello (Site 2) and Curacautín (Site 3); middle sector: Agua Fría (Site 4), Cajón (Site 5), Temuco-San Antonio (Site 6) and TemucoAmanecer (Site 7); finally in the low sector: Reñalil (Site 8), Boroa (Site 9) and Almagro (Site 10) (Figure 1). The altitude parameters (m.a.s.l) are listed in Table 1.

\subsection{Sampling procedures}

The physical-chemical variables (temperature, $\mathrm{pH}$, conductivity, and oxygen) were measured in situ using portable YSI-556 sensors. Substrate size was sampled using a core $(422 \mathrm{ml})$; the river's width, depth and stream velocity were measured according to the descriptions of Figueroa (2000), Figueroa et al. (2007).

Nine replicates were taken in each sampling site; in the high sector, samples were taken across a diagonal zone due to the narrowness of the river. The number of replicates was determined in advance using the asymptote of the curve between the number of species and the number of samples (Figueroa, 2000). In the selected sampling sites, the qualitative and quantitative characteristics of benthic macroinvertebrate communities were assessed. These were based on samples taken in the summers of 1997 and 2000, since the lower stream velocity in the summer season facilitates sampling procedures; it is also the period of maximum diversity. The substrate in the sampling sites consisted of rounded rocks (Hauer and Lamberti, 2007). Sampling procedures followed the descriptions of Dominguez and Fernandez (2009) using Surber samplers of $0.09 \mathrm{~m}^{2}$ with $250 \mu \mathrm{m}$ mesh size.

The samples collected were fixed in the field with $70 \%$ ethanol. The fauna was separated in the laboratory with a Zeiss binocular microscope; invertebrate specimens were determined using the descriptions of Fernández and Dominguez (2001) and Dominguez and Fernández (2009), mainly at genus and species level. However some individuals were determined at family and sub-family level due to the lack of specific taxonomic keys for particular groups native to South American inland waters. The results were expressed in density of individuals per square metre (Figure 2, Table 2). 


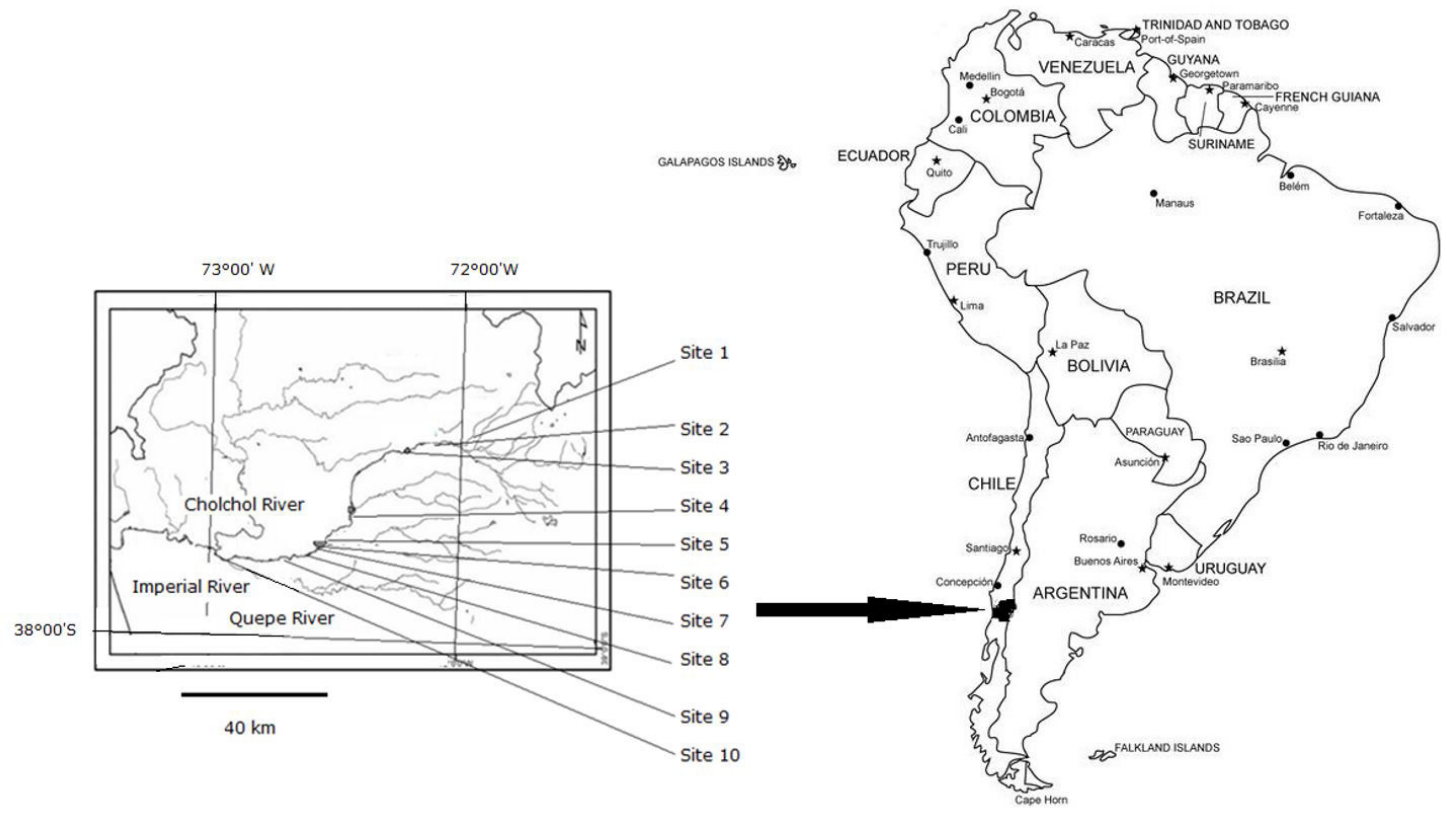

Figure 1. Map with sites on the Cautín River included in the present study.

Table 1. Geographical location, altitude and classification of the sampling sites on the main course of the Cautín River.

\begin{tabular}{lccccc}
\hline \multicolumn{1}{c}{ Name } & Site & $\begin{array}{c}\text { Latitude (S)/ } \\
\text { Longitude (W) }\end{array}$ & Altitude (m a.s.l) & Section & Human alteration \\
\hline Volcan Lonquimay & Site 1 & $38^{\circ} 26^{\prime} 13^{\prime \prime} / 71^{\circ} 30^{\prime} 33^{\prime \prime}$ & 1160 & High & Non-human altered \\
Malacahuello & Site 2 & $38^{\circ} 28^{\prime} 38^{\prime \prime} / 71^{\circ} 35^{\prime} 092^{\prime \prime}$ & 892 & High & Non-human altered \\
Curacautín & Site 3 & $3^{\circ} 28^{\prime} 32^{\prime \prime} / 71^{\circ} 56^{\prime} 52^{\prime \prime}$ & 445 & High & Non-human altered \\
Agua Fria & Site 4 & $3^{\circ} 28^{\prime} 16^{\prime \prime} / 72^{\circ} 19^{\prime} 15^{\prime \prime}$ & 280 & Middle & Agriculture/Town \\
Cajón & Site 5 & $38^{\circ} 40^{\prime} 54^{\prime \prime} / 72^{\circ} 30^{\prime} 15^{\prime \prime}$ & 120 & Middle & Agriculture/Town \\
Temuco (San Antonio) & Site 6 & $38^{\circ} 47^{\prime} 03^{\prime \prime} / 72^{\circ} 23^{\prime} 57^{\prime \prime}$ & 104 & Middle & Town \\
Temuco (Amanecer) & Site 7 & $38^{\circ} 45^{\prime} 23^{\prime \prime} / 72^{\circ} 36^{\prime} 53^{\prime \prime}$ & 97 & Midde & Town \\
Reñalil & Site 8 & $38^{\circ} 46^{\prime} 48^{\prime \prime} / 72^{\circ} 47^{\prime} 33^{\prime \prime}$ & 79 & Low & Agriculture \\
Boroa & Site 9 & $38^{\circ} 46^{\prime} 22^{\prime \prime} / 72^{\circ} 52^{\prime} 20^{\prime \prime}$ & 77 & Low & Agriculture \\
Almagro & Site 10 & $38^{\circ} 46^{\prime} 48^{\prime \prime} / 72^{\circ} 56^{\prime} 54^{\prime \prime}$ & 44 & Low & Agriculture \\
\hline
\end{tabular}

\subsection{Data analysis}

The community parameters were determined from the density analysis corresponding to the abundance of each species per sampling site, using the Shannon diversity index. Finally, the Shannon diversity indices for each site were compared based on the descriptions of Zar (1999).

In the third step, a redundancy analysis was applied for the physical-chemical and biotic variables studied, using the $\mathrm{R}$ software ( $\mathrm{R}$ Development Core Team, 2009), to determine the importance of the variables for classifying the sampling sites. A matrix correlation analysis using the parametric Pearson correlation coefficient was performed using the ggcorrplot package (Kassambara, 2019), with prior verification of normality and homoscedasticity conditions, in order to determine associations between the study variables. Principal component analysis (PCA) was carried out using the Vegan package (Oksanen et al., 2019).

\section{Results}

The benthic invertebrate fauna in the Cautín River consisted of at least 56 taxa, of which 48 were aquatic insects and 2 were crustaceans. Six taxa of Annellida and Mollusca were also found. The aquatic insects identified at species level were principally of the order Plecoptera (15 taxa), mainly belonging to the Gripopterygidae family ( 9 taxa); this was followed by the Ephemeroptera (12 taxa), especially the Leptophlebiidae family (8 taxa) (Table 2).

The distribution of Plecoptera was restricted mainly to high areas, with a few taxa in middle altitudes. A high proportion of Plecoptera species were found at the Curacautín site (Site 3 ). The absence of this taxon in Sites 6 and 7 was attributed to the effluent discharges found in Temuco. The family Gripopterygidae provided an essential contribution to species richness with nine species, notably Antarctoperla michaelseni 

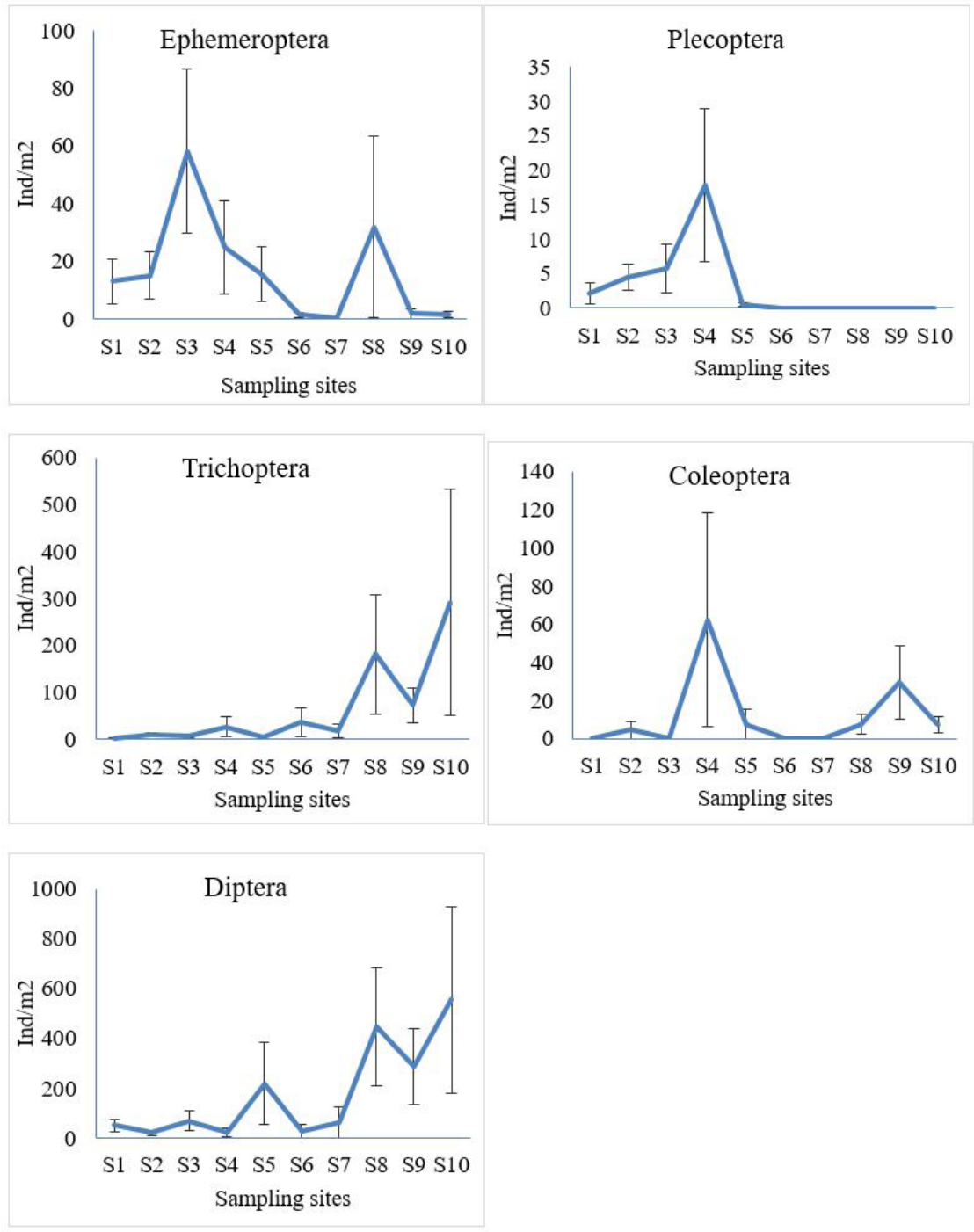

Figure 2. Longitudinal pattern of average density (ind $\left./ \mathrm{m}^{2}\right)$ of the main macroinvertebrates groups in the Cautín river. ( $\mathrm{S} 1=$ Site 1 ; $\mathrm{S} 2=$ Site $2 ; \mathrm{S} 3=$ Site $3 ; \mathrm{S} 4=$ Site $4 ; \mathrm{S} 5=$ Site $5 ; \mathrm{S6}=$ Site $6 ; \mathrm{S} 7=$ Site 7; S8 = Site 8; S9 = Site 9; S10 = Site 10).

and Pelurgoperla personata (Table 2, Figure 2). The Ephemeroptera showed a similar pattern to the Plecoptera, i.e. the taxa were distributed mainly in the high and middle sectors of the river. Some species, such as Deceptiviosa torrens and Andesiops peruviana, were widely distributed along the main course of the river; however, other species like Dactylobaetis sp., were restricted to the middle and high sections. In general terms, the Leptophlebidae presented the greatest abundance and species richness ( 8 species). The Ephemeroptera were absent from the sites located in Temuco (Sites 6 and 7) (Table 2, Figure 2). Trichoptera were widely distributed along the main course of the river, with low densities in the high sector but significantly higher densities in the low sector; the dominant species was Smicridea chilensis, which was present along the whole course of the river, including zones with maximum human intervention (Table 2, Figure 2).

The order Diptera was one of the most abundant groups in the Cautín River, being represented at all the sampling sites. Its mean density in the high and low sectors was double that of the middle sector. The subfamilies contributing most species were Orthocladiinae, Chironominae and Diamesinae. The taxa Edwardsina sp. and Limoniinae were present, restricted to the high sector (Table 2, Figure 2). The order Coleoptera had restricted distribution in the middle and low sectors of the river. Its mean density was obtained in Site 4; the Elmidae family was the most abundant at Sites 4 and 8, however these disappeared in the sites with greater human intervention (Sites 6 and 7) (Table 2, Figure 2).

The Mollusca and Annellida were restricted to the low sector of the river (Table 2, Figure 2). 
Table 2. Distribution and average abundance $\left(\right.$ ind $/ \mathrm{m}^{2}$ ) of the macrozoobenthos and community parameters along the Cautín River during study period in sampling sites.

\begin{tabular}{|c|c|c|c|c|c|c|c|c|c|c|}
\hline & Site 1 & Site 2 & Site 3 & Site 4 & Site 5 & Site 6 & Site 7 & Site 8 & Site 9 & Site 10 \\
\hline \multicolumn{11}{|l|}{ Annellida } \\
\hline Tubifex sp. & & & & 1 & & 56 & 15 & 28 & 24 & 6 \\
\hline Mesobdella gemmata (Blanchard, 1849) & & & & & & & 4 & 1 & & \\
\hline \multicolumn{11}{|l|}{ Mollusca } \\
\hline Chilina dombeyana (Brugière, 1789) & & & & & & & & 207 & 264 & 490 \\
\hline Physa chilensis Clessin, 1886 & & & & & & & & 39 & 24 & 13 \\
\hline Lymnaea viator (D’Orbigny, 1835) & & & & & & & & 1 & & \\
\hline Gundlachia gayana (D’Orbigny, 1895) & & & & & & & & 6 & 296 & 6 \\
\hline \multicolumn{11}{|l|}{ Crustacea, Decapoda } \\
\hline Aegla araucaniensis Jara, 1980 & & & 2 & & & & & & & \\
\hline A. abtao Jara, 1977 & & & 12 & & 3 & 67 & 2 & & & \\
\hline \multicolumn{11}{|l|}{ Insecta, Ephemeroptera } \\
\hline Chiloporter penai Demoulin, 1955 & & 1 & & & & & & & & \\
\hline Meridialaris diguillina (Demoulin, 1955) & 19 & 52 & 217 & 151 & 21 & 5 & & 1 & & 1 \\
\hline M. chiloeense (Demoulin, 1955) & 9 & 10 & & & & & & & & \\
\hline M. laminata (Ulmer, 1920) & & 1 & & & & & & & & \\
\hline Hapsiphlebia anastomosis (Demoulin, 1955) & & & 1 & & & & & & & \\
\hline Nousia delicata Návas, 1918 & & 16 & 59 & & 6 & & & & & \\
\hline N. maculata (Demoulin, 1955) & & & 67 & & & & & & & \\
\hline N. minor (Demoulin, 1955) & & & 10 & & & & & & & \\
\hline Penaphlebia sp. (Ulmer, 1920) & & & 4 & 3 & 16 & & & & & \\
\hline $\begin{array}{l}\text { Deceptiviosa torrens (Lugo-Ortiz \& } \\
\text { McCafferty, 1999) }\end{array}$ & 88 & 7 & & 8 & 3 & 11 & & 1 & & 3 \\
\hline Andesiops peruviana (Ulmer, 1920) & 40 & 93 & 280 & 136 & 116 & & & 376 & 19 & 14 \\
\hline Dactylobaetis sp. & & & & & 22 & & & 4 & & \\
\hline Klapopteryx armillata Návas, 1928 & 12 & & & & & & & & & \\
\hline K. kuscheli Illies, 1960 & & 6 & 1 & & & & & & & \\
\hline Potamoperla myrmidon (Mabille, 1881) & & 2 & 2 & 28 & & & & & & \\
\hline Notoperlopsis femina Illies, 1863 & 1 & 16 & 1 & 76 & 2 & & & & & \\
\hline Senzilloides panguipulli (Navas, 1928) & 1 & & & & & & & & & \\
\hline Teutoperla sp. & 1 & 1 & & & & & & & & \\
\hline Aubertoperla sp. & 9 & 2 & & 154 & 2 & & & & & \\
\hline Limnoperla jaffueli (Navas, 1928) & 0 & 7 & 14 & & & & & & & \\
\hline Perlugoperla personata Vera, 2008 & 19 & 27 & 2 & & & & & & & \\
\hline Ceratoperla schwabei Illies, 1963 & & & 2 & & & & & & & \\
\hline Antarctoperla michaelseni (Klapácek, 1904) & & 5 & 53 & & & & & & & \\
\hline Austronemoura sp. & & & & 1 & & & & & & \\
\hline Udamocercia sp. & & & 4 & & & & & & & \\
\hline Pictetoperla gayi (Pictet, 1841) & & & 4 & 7 & 3 & & & & & \\
\hline \multicolumn{11}{|l|}{ Insecta, Plecoptera } \\
\hline Diamphipnoa sp. & 1 & & 2 & & & & & & & \\
\hline Hydrobiosidae & & 1 & & 1 & & & & & & \\
\hline \multicolumn{11}{|l|}{ Insecta, Trichoptera } \\
\hline Smicridea chilensis Schmid, 1950 & 10 & 30 & 20 & 150 & & 211 & 104 & 903 & 261 & 1696 \\
\hline Ochrotrichia sp. & 1 & & 1 & & 3 & & & 3 & & 6 \\
\hline Glossomatidae indet. & 1 & 25 & & & 21 & & & & 94 & \\
\hline Limnephilidae & & & 25 & & & & & 178 & 79 & 44 \\
\hline Leptoceridae & & 1 & & 3 & & & & & & \\
\hline Helicopsychidae & & 1 & & 1 & & & & & & 1 \\
\hline \multicolumn{11}{|l|}{ Insecta, Coleoptera } \\
\hline Amphizoidae & & & & 26 & & & & & & \\
\hline Dytiscidae & & & & & & & & & 47 & \\
\hline Andogyrus sp. & & & & & & & & 3 & & \\
\hline Elmis sp. & & 22 & & 285 & 38 & & & 28 & 97 & 19 \\
\hline
\end{tabular}


Table 2. Continued..

\begin{tabular}{|c|c|c|c|c|c|c|c|c|c|c|}
\hline & Site 1 & Site 2 & Site 3 & Site 4 & Site 5 & Site 6 & Site 7 & Site 8 & Site 9 & Site 10 \\
\hline Hydrophilidae & & & & & & & & 6 & 3 & 17 \\
\hline \multicolumn{11}{|l|}{ Insecta, Diptera } \\
\hline Tanypodinae & 30 & & 1 & & & & & 158 & 222 & 290 \\
\hline Diamesinae & 102 & & 57 & & 103 & & & 1428 & 211 & 153 \\
\hline Chironominae & 109 & & 157 & & 1516 & & & 513 & 593 & 656 \\
\hline Orthocladiinae & 212 & & 22 & & 295 & 230 & 559 & 1875 & 1410 & 3496 \\
\hline Rheotanytarsus sp. & & 2 & & 24 & & & & 26 & 143 & 392 \\
\hline Limoniinae & & 94 & 362 & 164 & 51 & 14 & & & & \\
\hline Simulium sp. & & & 1 & & & & & & & \\
\hline Athericidae & 5 & 11 & 15 & 3 & 5 & & & & & 1 \\
\hline Edwardsina sp. & 4 & 70 & & & & & & & & \\
\hline
\end{tabular}

The total mean density increased from the high sector to the low sector, with principal contributions by Smicridea chilensis and the Orthocladiinae (Table 2). The community parameters analysed in the Shannon Index and the diversity index present high values in the high sector of the river, which is consistent with the low level of urban zones. A marked decrease in species diversity was observed lower down, mainly at the sites located in Temuco (Sites 6 and 7) (Table 3).

The correlation matrix revealed the existence of significant direct associations $(P>0.05)$. One group with directly correlated variables linked width, depth, altitude, dissolved oxygen, $\mathrm{pH}$, temperature, Tubifex and Mesobdella gemmata (Figure 3). Substrate was directly related with velocity, Chiloporter pennai and Aegla abtao (Figure 3), and altitude with Limnoperla jaffueli, Austroperla sp., Teutoperla sp., Senzilloides panguipulli, and Notoperlopsis femina (Figure 3). Physa chilensis, Aegla abtao, Ch. penai, Meridianalis diguillina, M. chiloense, M. laminata, Hapsiphlebia anastomis, Nousia delicata, N. maculata, N. minor, Penophlebia sp., Baetis sp., Pseudocleon sp. and Dactylobaetis sp. were directly correlated with one another (Figure 3). Similar results were observed for Chilina dombeyana with Pseudocleon sp., M. chiloense, A. abtao, A. araucaniensis, and Physa chilensis; Limnea vitor with Chilina dombeyana, A. abtao and Gundachia gayana; G. gayana with L. jaffueli; A. araucaniensis with Smicridea chilensis; Potamoperla with Austromenura, Antarctoperla and Ceratoperla (Figure 3). Klapopteryx armillata, Austronemura sp., Antarctoperla michaelseni, Ceratoperla schwabei, Pelurgoperla personata, $N$. femina, Potamoperla myrmidon and K. kuscheli were all directly correlated (Figure 3). K. armillata, K. kuscheli, P. myrmidon, N. femina, S. panguipulli, Teutoperla sp., A. michaeseni and Pelurgoperla personata were directly correlated with C. schwabei and L. jaffueli (Figure 3); $N$. femina and L. jaffueli were directly correlated with $P$. personata; whereas $N$. femina, S. panguipulli, and Teutoperla sp., were directly correlated with one another (Figure 3). Also, A. michaelseni, Udomercia sp. and Pictoperla gayi (Figure 3), Ochotrichia sp., Glossomotidae, Limnephidae, Leptoceridae all were directly correlated, and Smicridea chilensis was directly correlated with this group (Figure 3); Ochotrichia sp. was directly correlated with Chironomidae, density, species richness Edwarsina sp., and Athericidae; Glossomatidae with density and species richness (Figure 3); Amphizoidae with Disticidae and species richness (Figure 3). Also, Dytiscidae, Andogyrus sp., and Elmis sp. were all directly correlated; Hydrophilidae and Tanypodidae were directly correlated with Chironomidae and Diamesinae; and finally, density was directly correlated with Chironomidae, Pheotanytarsus sp., Limoniidae, Simulium sp., Athericidae, Edwarsina sp., Shannon index and species richness (Figure 3).

Significant inverse relations were observed for Limoniidae with $P$. chilensis, Lymnea viator and G. gayana which simultaneously was inversely correlated with Chironomidae. L. viator was correlated with Glossomotidae, and $L$ viator with Pictoperla gayi and Udamoceria sp.; these three were inversely correlated with G. gayana and these four were inversely correlated with Chilina dombeyana (Figure 3). Finally, L. jaffueli was inversely correlated with Diamphanoa sp. and S. chilensis, and Diamphanoa sp. with Athericidae (Figure 3).

The RDA results revealed that the main environmental contributor variable for axis 1 was altitude, with smaller contributions by substrate, temperature and dissolved oxygen; the main contributors for axis 2 were depth and altitude, with smaller contributions by substrate, width, temperature and dissolved oxygen (Table 4). In biotic parameters, the main contributors for axis 1 were Smicridea chilensis, Chironomidae, Ortocladinae, and density; whereas for axis 2 the main contributor variables were Chilina dombeyana, Meridianalis diguillina, Pseudocleon sp., Smicridea chilensis, Elmis sp., Diamesinae, Chiromonidae sp., Orthocladiinae sp.,Thaeotanytarsus sp., Limoniidae and density (Table 4).

The RDA revealed the existence of two main groups: the first group included the sites in the low sector, with high density, temperature, width, $\mathrm{pH}$ values, and abundances of Orthocladiinae, Chironomidae and Smicridea chilensis (Figure 4). The second group includes sites in the high sector (Sites 1, 2 and 3) with high altitude, depth, dissolved oxygen concentration, conductivity and total dissolved solids (Figure 4), and - relatively distant - sites in the middle sector (Sites 6 and 7) (Figure 4). Finally Site 5 is the most different site, with a high velocity value (Figure 4 ).

The results of the comparison of the diversity indices show significant differences between each site (Table 5). 
Table 3. Altitude, substrate size, width, sampling depth, stream velocity, temperature, and dissolved oxygen along the Cautín River during study period in sampling sites.

\begin{tabular}{lcccccccccc}
\hline & Site 1 & Site 2 & Site 3 & Site 4 & Site 5 & Site 6 & Site 7 & Site 8 & Site 9 & Site 10 \\
\hline Altitude (m a.s.l) & 1160 & 892 & 445 & 280 & 120 & 104 & 97 & 79 & 77 & 44 \\
Substrate size $(\mathrm{cm})$ & 7.00 & 18.20 & 20.50 & 19.21 & 14.39 & 9.56 & 9.10 & 6.83 & 9.03 & 9.42 \\
Width $(\mathrm{m})$ & 6 & 18 & 35 & 30 & 60 & 126 & 86 & 40 & 56 & 73 \\
River depth $(\mathrm{cm})$ & 0.30 & 0.40 & 0.48 & 0.60 & 0.40 & 0.50 & 0.60 & 0.55 & 0.33 & 0.21 \\
Stream velocity $(\mathrm{m} / \mathrm{s})$ & 0.90 & 0.60 & 1.70 & 1.10 & 0.50 & 0.30 & 0.30 & 1.20 & 0.50 & 0.60 \\
Temperature $\left({ }^{\circ} \mathrm{C}\right)$ & 12.0 & 13.0 & 13.0 & 13.5 & 17.0 & 17.2 & 17.6 & 18.6 & 20.0 & 23.0 \\
pH & 7.5 & 7.5 & 8.0 & 7.5 & 8.5 & 7.9 & 7.7 & 7.5 & 8.0 & 8.5 \\
Dissolved oxygen $(\mathrm{mg} / \mathrm{l})$ & 10.8 & 10.6 & 10.6 & 10.5 & 9.7 & 8.9 & 8.8 & 9.4 & 9.2 & 8.7 \\
\hline
\end{tabular}
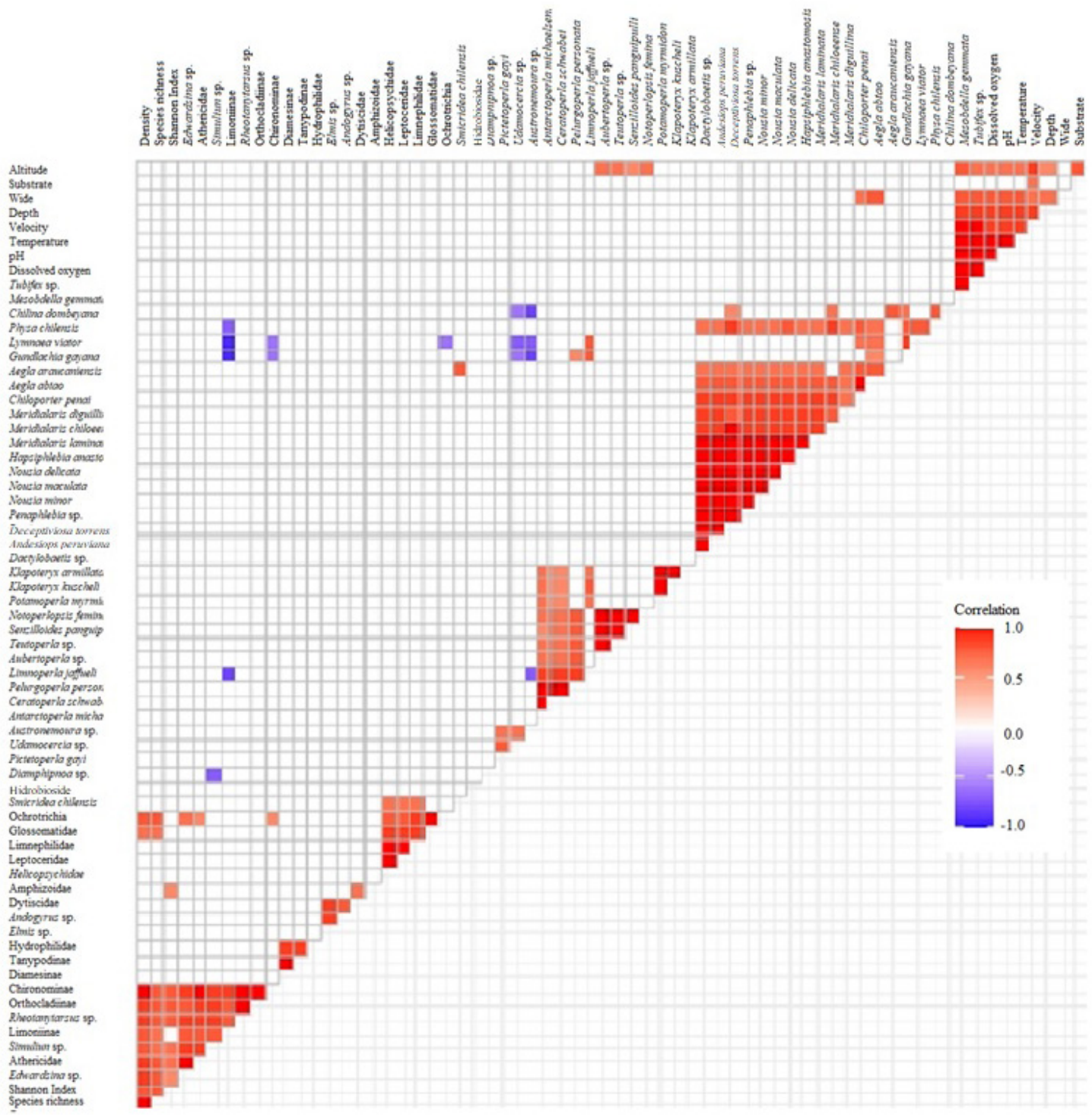

Figure 3. Correlation matrix for PCA for physical-chemical and biotic parameters for sites studied along the Cautín River. 
Figueroa, D. and De los Rios-Escalante, P.

Table 4. Redundance analysis (RDA) for the variables considered in the present study

\begin{tabular}{|c|c|c|}
\hline \multicolumn{3}{|c|}{ Environmental variables } \\
\hline & Axis 1 & Axis 2 \\
\hline Altitude & 1354.39 & -3.73 \\
\hline Substrate & -178.00 & -20.23 \\
\hline Width & -165.28 & 150.47 \\
\hline Depth & -214.80 & -40.49 \\
\hline Velocity & $-213-79$ & -40.34 \\
\hline Temperature & -188.26 & -0.11 \\
\hline $\mathrm{pH}$ & -200.01 & -23.82 \\
\hline Dissolved oxygen & -194.22 & -21.72 \\
\hline \multicolumn{3}{|c|}{ Biotic parameters } \\
\hline Tubifex sp. & -323.84 & 11.55 \\
\hline Mesobdella gemmata & -355.02 & 13.36 \\
\hline Chilina dombeyana & 200.34 & 171.36 \\
\hline Physa chilensis & -317.38 & 7.84 \\
\hline Lymnaea viator & -355.32 & 12.83 \\
\hline Gundlachia gayana & -243.13 & -25.69 \\
\hline Aegla araucaniensis & -355.62 & 12.50 \\
\hline Aegla abtao & -349.93 & 11.29 \\
\hline Chiloporter penai & -355.80 & 12.97 \\
\hline Meridialaris diguillina & -307.64 & -88.14 \\
\hline Meridialaris chiloeense & -354.89 & 11.80 \\
\hline Meridialaris laminata & -355.80 & 12.97 \\
\hline Hapsiphlebia anastomosis & -355.73 & 12.77 \\
\hline Nousia delicata & -347.36 & -8.68 \\
\hline Nousia maculata & -348.29 & -5.21 \\
\hline Nousia minor & -354.72 & 10.32 \\
\hline Penaphlebia sp. & -351.91 & -0.63 \\
\hline $\begin{array}{l}\text { Deceptiviosa torrens (Lugo-Ortiz \& } \\
\text { McCafferty, 1999) }\end{array}$ & -345.44 & 5.51 \\
\hline Andesiops peruviana (Ulmer, 1920) & -66.58 & -255.20 \\
\hline Dactylobaetis sp. & -349.34 & -4.51 \\
\hline Klapoteryx armillata & -355.10 & 12.30 \\
\hline Klapoteryx kuscheli & -355.49 & 12.36 \\
\hline Potamoperla myrmidon & -352.80 & 8.30 \\
\hline Notoperlopsis femina & -347.19 & -0.94 \\
\hline Senzilloides panguipulli & -355.78 & 12.98 \\
\hline Teutoperla sp. & -355.74 & 12.91 \\
\hline Aubertoperla sp. & -339.73 & -11.51 \\
\hline Limnoperla jaffueli & -353.99 & 8.75 \\
\hline Pelurgoperla personata & -353.37 & 9.47 \\
\hline Ceratoperla schwabei & -355.62 & 12.50 \\
\hline Antarctoperla michaelseni & -349.67 & -1.74 \\
\hline Austronemoura sp. & -355.75 & 12.90 \\
\hline
\end{tabular}


Table 4. Continued...

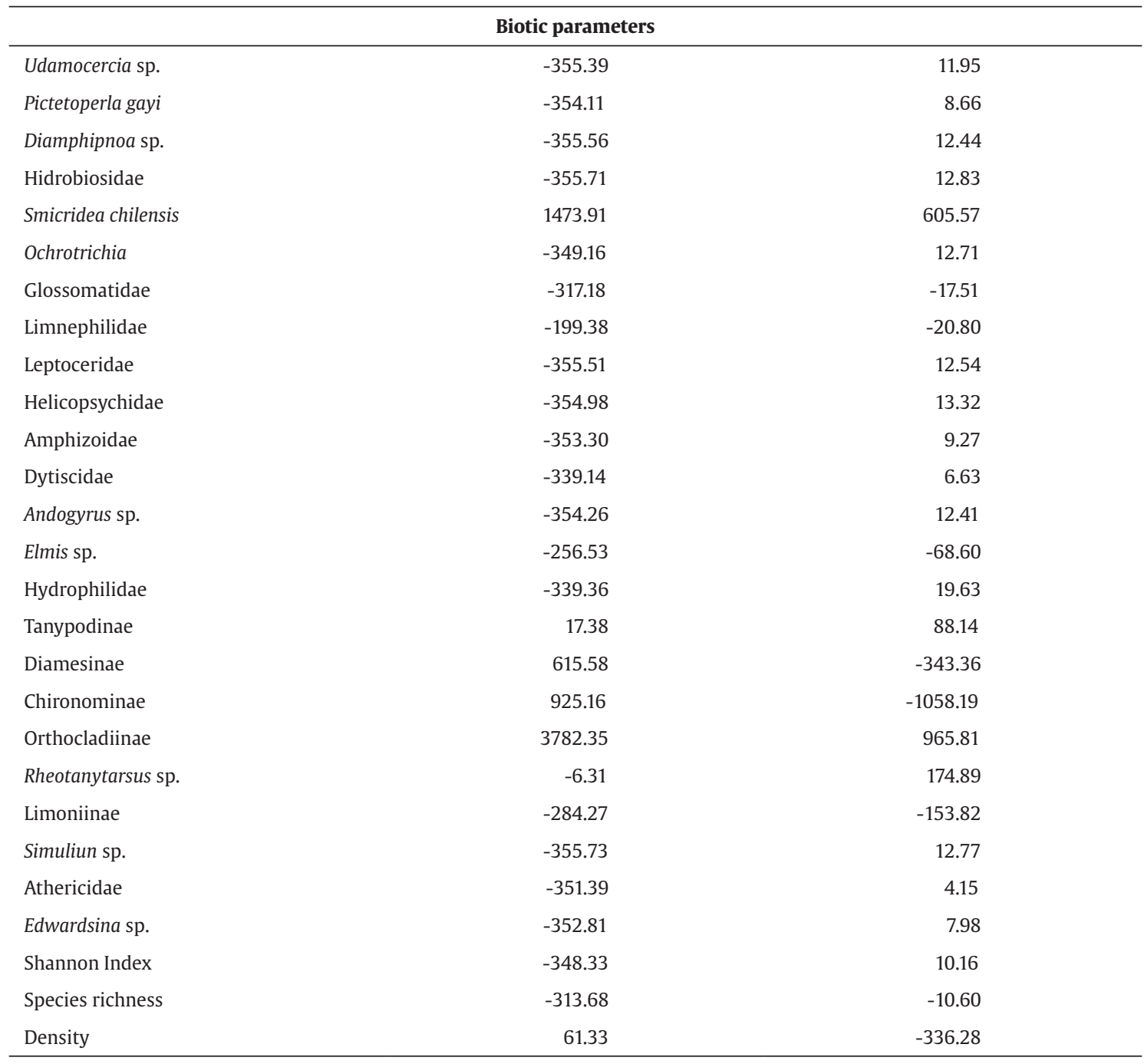

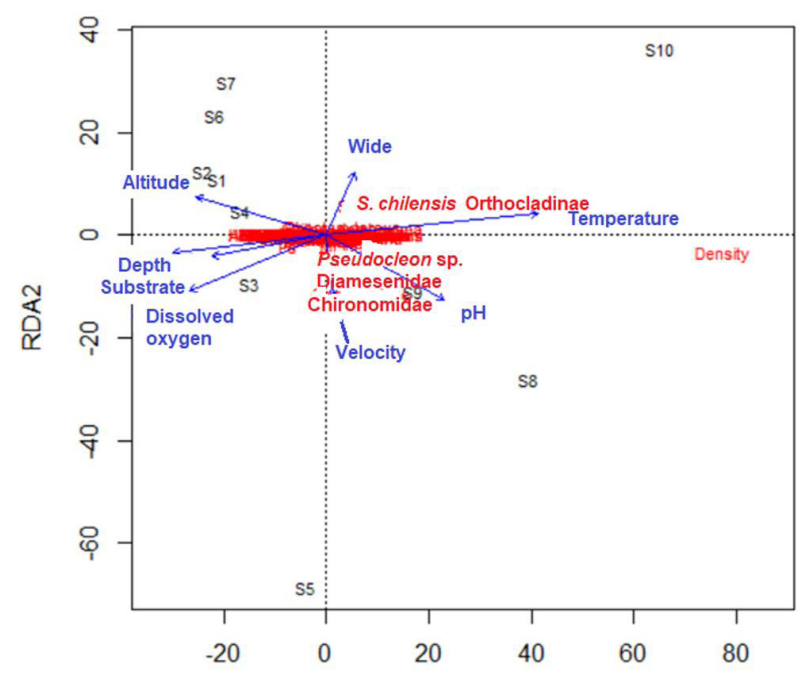

Figure 4. Results of RDA for physical-chemical and biotic parameters for sites studied along the Cautín River. 
Table 5. Results of Shannon index comparison between each sampling site along the Cautín River. $($ T table $=1.960)$

\begin{tabular}{|c|c|c|c|c|c|}
\hline Sites & $\mathbf{T}$ & $\mathbf{P}$ & Sites & $\mathbf{T}$ & $\mathbf{P}$ \\
\hline Site 1 / Site 2 & 5.024 & $<0.01$ & Site 3 / Site 9 & -29.485 & $<0.01$ \\
\hline Site 1 / Site 3 & -14.863 & $<0.01$ & Site 3/ Site 10 & -51.891 & $<0.01$ \\
\hline Site 1 / Site 4 & -13.101 & $<0.01$ & Site 4 / Site 5 & -16.166 & $<0.01$ \\
\hline Site 1 / Site 5 & -24.276 & $<0.01$ & Site 4 / Site 6 & 18.188 & $<0.01$ \\
\hline Site 1 / Site 6 & 2.469 & $<0.01$ & Site 4 / Site 7 & 14.117 & $<0.01$ \\
\hline Site 1 / Site 7 & -0.281 & $<0.01$ & Site 4 /Site 8 & -60.157 & $<0.01$ \\
\hline Site 1 / Site 8 & -51.929 & $<0.01$ & Site 4 / Site 9 & -40.097 & $<0.01$ \\
\hline Site 1 / Site 9 & -40.223 & $<0.01$ & Site 4 / Site 10 & -69.141 & $<0.01$ \\
\hline Site 1 / Site 10 & -57.549 & $<0.01$ & Site 5 /Site 6 & 30.053 & $<0.01$ \\
\hline Site 2 / Site 3 & -19.700 & $<0.01$ & Site 5 / Site 7 & 170.286 & $<0.01$ \\
\hline Site 2 / Site 4 & -18.326 & $<0.01$ & Site 5 / Site 8 & -21.099 & $<0.01$ \\
\hline Site 2 / Site 5 & -24.276 & $<0.01$ & Site 5 / Site 9 & -15.634 & $<0.01$ \\
\hline Site $2 /$ Site 6 & 2.469 & $<0.01$ & Site 5 / Site 10 & -37.058 & $<0.01$ \\
\hline Site 2 / Site 7 & -0.281 & $<0.01$ & Site 6 / Site7 & -2.977 & $<0.01$ \\
\hline Site 2 / Site 8 & -51.929 & $<0.01$ & Site 6 / Site8 & -65.056 & $<0.01$ \\
\hline Site 2 / Site 9 & -40.223 & $<0.01$ & Site 6 / Site9 & -50.383 & $<0.01$ \\
\hline Site 2 / Site 10 & -57.549 & $<0.01$ & Site 6 / Site 10 & -71.699 & $<0.01$ \\
\hline Site 3 / Site 4 & 3.644 & $<0.01$ & Site 7 / Site 8 & -58.310 & $<0.01$ \\
\hline Site 3 / Site 5 & -11.207 & $<0.01$ & Site 7 / Site 9 & -44.660 & $<0.01$ \\
\hline Site 3 / Site 6 & 19.536 & $<0.01$ & Site 7 / Site 10 & -64.661 & $<0.01$ \\
\hline Site 3 / Site 7 & 15.842 & $<0.01$ & Site 8 / Site 9 & 20.043 & $<0.01$ \\
\hline Site 3 / Site 8 & -44.589 & $<0.01$ & Site 8 / Site 10 & -13.037 & $<0.01$ \\
\hline
\end{tabular}

\section{Discussion}

In zoogeographical terms, the community studied corresponds to Neotropical fauna of Southern South America, with endemic characteristics due to the marked bio-geographical isolation of Chile (Morrone, 2015). The macroinvertebrates in the Cautín River consisted of dominant groups belonging to the orders Ephemeroptera, Plecoptera, Trichoptera, and Diptera. This fauna has been reported for ritronic habitats located in the cold-temperate zone (Figueroa et al., 2007; De los RíosEscalante et al., 2020), similar to reports from the northern hemisphere (Hauer and Lamberti, 2007).

In this research, differences were found in the taxonomic composition and distribution of the community associated with the physical and chemical characteristics of this fluvial system as a function of its altitude. This agrees with descriptions of Miserendino et al. (2018) for Argentinean Patagonia, where the main changes are observed in the middle riverbed zones due to decreasing substrate size and oxygen concentration, and increasing temperature. The species reported in the present study agree with the results reported by Vega et al. (2020), in a species inventory along the whole Cautín River with no sites specified; this differs from the present study in which the species were associated with different sites.

The diversity and richness analyses in high zones of the Cautin River show variation attributable to the physical conditions of the riverbed and the influence of the environment at each sampling site. The results of fitting the composition and distribution patterns observed in ritronic zones correspond to stenothermal fauna consisting of larvae of the orders Ephemeroptera, Plecoptera, and Trichoptera (Figueroa et al., 2007; Miserendino et al., 2018). The riverbed was influenced by its environment, with native shrubs providing organic matter inputs.

Finally, the increases in riverbed exposure show gradual development of the phytobenthos, allowing the appearance of feeding functional groups (Allan and Del Castillo, 2007), as was reported by Miserendino et al. (2018). The decreases in species richness and diversity in the middle and low sectors are explained by the natural transformation of the riverbed and marked human intervention (Santiago et al., 2016).

The medium and low sectors of the river are marked by large areas of arable and livestock farming (from Curacautín to Lautaro; Santiago et al., 2016). Another important factor is the urban waste water discharged into the Cautín River at Temuco (San Antonio and Amanecer sites), resulting in decreased species richness at both these sites. Figueroa et al. (2007) mentioned that non-human altered sites on the riverbed presented abundant taxonomic richness of insects of the orders Ephemeroptera, Plecoptera and Trichoptera. Sites affected by human intervention, in contrast, present low taxonomic richness, and generally with a community 
represented mainly by Oligochaeta and Mollusca. Similar results are described by Allan and Del Castillo (2007) and Hauer and Lamberti (2007). Huttunen et al. (2017) and Marcarelli et al. (2020) reported that the fish and invertebrate communities present decreased density, richness and diversity in more urban areas; the species richness decreases where the nutrient contents increase mainly nitrites due to agricultural and industrial pollution.

Interpretation of the distribution of macroinvertebrates along river courses has been widely discussed since the publication of the river continuum concept (Allan \& Del Castillo, 2007), which proposes the gradual replacement of different species along riverbeds in natural conditions without human intervention. The most numerous species in these sectors were Meridialaris chiloense, Nousia delicata, Pelurgoperla personata and Ceratoperla schwabei, consistent with their environmental requirements for cold, highly oxygenated, turbulent water (Miserendino et al., 2018). These restricted distributions of Ephemeroptera and Plecoptera have been described for Argentinean and Chilean Patagonian river systems (Arenas, 1995; Oyanedel et al., 2008; Moya et al., 2009; Figueroa et al., 2007; Miserendino et al., 2018; De los Ríos-Escalante et al., 2020; Barile et al., 2021).

In another context, it was noted that many of these species decrease in abundance and presence in low zones of the river, mainly in sites with high urban influence such as Lautaro, Temuco, Labranza and Imperial. These results coincide with the macroinvertebrate community found in middle sector zone sites with greatest human intervention. Similar findings were described by Figueroa (2000) and Figueroa et al. (2007) for rivers associated with urban areas in south central Chile. Many of the species described for high sector zones, especially Ephemeroptera and Plecoptera, disappear in the Temuco sites (6 and 7); this is due to the marked human intervention with resulting deterioration in environmental quality. Vega et al. (2020) state that the water quality of the Cautín River has been harmed by increasing concentrations of contaminants and decreased flow in recent years (Rivera et al., 2004; Santiago et al. 2016; Fernández et al., 2018; Acuña, 2020). Up to the time of the present study, some 27 industrial plants havebeen recorded in Temuco that discharge their liquid effluents directly into the Cautín River without previous treatment (Rivera et al., 2004; Santiago et al., 2016; Fernández et al., 2018; Acuña, 2020).

In the distribution analysis, it was observed that taxa with wide distribution along the main course of the river, such as Meridialaris diguillina, Andesiops peruviana, Smicridea chilensis and sub-families Chironominae, Orthocladiinae, and Diamesinae, present their maximum densities in the middle and lower sectors of the river (Scheibler et al., 2014); however, many of these taxa disappear in sites with greater alteration by waste water. Allan and Del Castillo (2007) described a marked decrease of species diversity in fish and macroinvertebrate communities in urban areas, increasing over in periods in excess of 30 years; the composition of these communities is affected principally by agricultural, industrial and urban development factors.
The high tolerance of the Orthocladiinae and Chironomidae sub-families accounts for their predominance under altered environmental conditions. Allan and Del Castillo (2007) reported that both these groups have respiratory pigments that allow them to survive in environments with low oxygenation and high organic load; this agrees with the findings of low oxygen concentration in these zones and the correlations found between abiotic community parameters on the one hand and richness and diversity on the other (Table 2; Figueroa et al., 2007).

Different species were observed in the low sector of the Cautín River, such as Mollusca and Annellida: Chilina dombeyana, Gundlachia gayana, Physa chilensis, Mesobdella gemmata and Tubifex sp; these taxa are characteristic of zones with high temperature and nutrient concentrations. Arenas (1995) described similar results in the Bíobío River. Figueroa et al. (2007) proposed that these species are directly related to urban water discharges, a suggestion that agrees with the results obtained in the present study.

The distribution data of the benthic macroinvertebrate communities of the Cautín River have been compared with historical data from 1986 (Vega et al., 2020); this report showed the changes in the benthic macroinvertebrate community since a study dating to 34 years before the present, when the benthic communities located in Temuco (Sites 6 and 7) had a similar composition to that currently recorded in high sector sites. This would confirm the altered state of the lower sectors. On the basis of this comparison, and the findings reported in the present analysis, the communities currently restricted to the high sector used to be more widely distributed down the Cautín River as far as Temuco, reflecting the much better water conditions in the mid-1980s. This would be useful information for managing areas of significant risk for benthic communities in the future, as human activities in the basin continue to expand (Santiago et al., 2016).

The results obtained for the taxonomic identification, distribution and abundance of benthic macroinvertebrate communities in the Cautín River allows the natural variation in species along the river to be deduced (Vega et al., 2020) and differentiated from the communities found in zones influenced by human intervention, fundamentally through variations in the abundance of widely distributed species (Figueroa et al., 2007). This information allows river sections with little or no intervention to be compared with those where human activities have developed more strongly, highlighting the effects in urbanised zones of factors such as urban and industrial waste water or sand and gravel extraction.

Finally, the species composition reported for the Cautín River suggests areas where further research is required, such as the techniques used in taxonomic determination. In this context, Hauer and Lamberti (2007) suggested that the use of varying levels of determination (genus and species) make it more difficult to compare river systems. Furthermore, determination at species level requires the presence of specialists who are scarce in Chile; this means that comparisons are difficult to generate, or must be restricted to certain faunal groups. 


\section{Acknowledgements}

The authors express their gratitude for funding of this research by Projects 97.03.04 of the Research Department of the Catholic University of Temuco, and MECESUP UCT 0804. We also thank the technicians Manuel Escudero and Robert Llamunao for their collaboration in the field and the laboratory. Finally, we thank M.I and S.M.A for improving the information of this manuscript.

\section{References}

ACUÑA, P., 2020. Modeling the hydrological response of a southern Chilean watershed to climate change. Zurich, Switzerland: ETH Zurich, 54 p. MsC Thesis of Advanced Studies in Sustainable Water Resources.

ALLAN, J.D. and DEL CASTILLO, M.M., 2007. Stream ecology, structure and function of running waters. 2nd ed. USA: Springer, $436 \mathrm{p}$.

ARENAS, J., 1995. Composición y distribución del macrozoobentos del curso principal del rio Biobio, Chile. Medio Ambiente, vol. 12, no. 2, pp. 39-50.

BARILE, J., VEGA, R. and DE LOS RIOS-ESCALANTE, P., 2021. First report the role of the benthic macroinvertebrates as preys for native fish in Tolten river $\left(38^{\circ} \mathrm{S}\right.$, Araucania region, Chile). Brazilian Journal of Biology = Revista Brasileira de Biologia, vol. 81, no. 3, pp. 845-853. http://dx.doi.org/10.1590/15196984.232661.

DE LOS RIOS-ESCALANTE, P., ESSE, C., SANTANDER-MASSA, R., SAAVEDRA, P. and ENCINA-MONTOYA, F., 2020. Benthic macroinvertebrate communities in sites with native forest presence and absence in north Patagonia. Iheringia. Série Zoologia, vol. 110, pp. e2020014. http://dx.doi.org/10.1590/16784766e2020014.

DOMINGUEZ, E. and FERNANDEZ, H.R., eds., 2009. Macroinvertebrados bentónicos sudamericanos. Sistemática y Biología. San Miguel de Tucuman, Argentina: Fundación Miguel Lillo, 656 p.

FERNÁNDEZ, A., MUÑOZ, A., GONZÁLEZ-REYES, A., AGUILERABETTI, I., TOLEDO, I., PUCHI, P., SAUCHYN, D., CRESPO, S., FRENE, C., MUNDO, I., GONZÁLEZ, M. and VINOLA, R., 2018. Dendrohydrology and water resources management in south-central Chile: lessons from the Rio Imperial streamflow reconstruction. Hydrology and Earth System Sciences, vol. 22, no. 5, pp. 2921-2935. http://dx.doi.org/10.5194/hess22-2921-2018.

FERNÁNDEZ, H.R. and DOMÍNGUEZ, E., eds., 2001. Guía para la determinación de los artrópodos bentónicos sudamericanos. San Miguel de Tucumán, Argentina: Editorial Universitaria de Tucumán, Fundación Miguel Lillo, 282 p.

FIERRO, P., BERTRAN, C., MERCADO, M., PENA CORTES, F., TAPIA, J., HAUENSTEIN, E., CAPUTO, L. and VARGAS CHACOFF, L., 2015. Landscape composition as determinant of diversity and functional feeding groups of aquatic macroinvertebrates in southern rivers of the Araucania, Chile. Latin American Journal of Aquatic Research, vol. 43, no. 1, pp. 186-200. http://dx.doi. org/10.3856/vol43-issue1-fulltext-16.

FIGUEROA, D., 2000. Efectos de la urbanización sobre las comunidades de macroinvertebrados bentónicos, en el curso principal del río Cautín, IX, región, Chile. Chile: Universidad Austral de Chile, 77 p. MsC Thesis.

FIGUEROA, R., VALDOVINOS, C., ARAYA, E., and PARRA, O., 2003. Macroinvertebrados bentónicos como indicadores de calidad de agua de ríos del sur de Chile. Revista Chilena de Historia Natural, vol. 76, no. 2, pp. 275-285. http://dx.doi.org/10.4067/ S0716-078X2003000200012.

FIGUEROA, R., PALMA, A., RUIZ, V. and NIELL, X., 2007. Análisis comparativo de índices bióticos utilizados en la evaluación de la calidad de aguas en un río mediterráneo de Chile, río Chillán, VIII región. Revista Chilena de Historia Natural, vol. 80, no. 2, pp. 225-242. http://dx.doi.org/10.4067/S0716078X2007000200008.

HAUER, F.R. and LAMBERTI, G.A., 2007. Methods in stream ecology. Cambridge: Academic Press, 865 p.

HUTTUNEN, K.L., MYKRÄ, H., OKSANEN, J., ASTORGA, A., PAAVOLA, R. and MUOTKA, T., 2017. Habitat connectivity and in-stream vegetation contron temporal variability of benthic invertebrate communities. Scientific Reports, vol. 7, no. 1, pp. 1448. http:// dx.doi.org/10.1038/s41598-017-00550-9. PMid:28469187.

KASSAMBARA, A., 2019 [viewed 4 October 2020]. Visualization of a Correlation Matrix using 'ggplot2'. Package 'ggcorrplot' [online]. Available from: https://cran.r-project.org/web/packages/ ggcorrplot/ggcorrplot.pdf

MARCARELLI, A.M., BAXTER, C.V., BENJAMIN, J.R., MIYAKE, Y., MURAKAMI, M., FAUSCH, K.D. and NAKANO, S., 2020. Magnitude and direction of stream-forest community interactions change with timescale. Ecology, vol. 101, no. 8, pp. e03064. http:// dx.doi.org/10.1002/ecy.3064. PMid:32274791.

MISERENDINO, M.L., BRAND, C., EPELE, L.B., DI PRINZIO, C.Y., OMAD, G.H., ARCHANGELSKY, M., MARTÍNEZ, O. and KUTSCHKER, A.M., 2018. Biotic diversity of benthic macroinvertebrates at contrasting glacier-fed systems in Patagonia Mountains: the role of environmental heterogeneity facing global warming. The Science of the Total Environment, vol. 622-623, pp. 152-163. http://dx.doi.org/10.1016/j. scitotenv.2017.11.320. PMid:29212052.

MORRONE, J.J., 2015. Biogeographical regionalisation of the Andean region. Zootaxa, vol. 3936, no. 2, pp. 207-236. http://dx.doi. org/10.11646/zootaxa.3936.2.3. PMid:25947431.

MOYA, C., VALDOVINOS, C., MORAGA, A., ROMERO, F., DEBELS, P. and OYANEDEL, A., 2009. Patrones de distribución espacial de ensambles de macroinvertebrados bentónicos de un sistema fluvial Andino Patagónico. Revista Chilena de Historia Natural, vol. 82, no. 3, pp. 425-442. http://dx.doi.org/10.4067/S0716078X2009000300009.

OKSANEN, J., BLANCHET, F.G., FRIENDLY, M., KINDT, R., LEGENDRE, P., MCGLINN, D., O'HARA, R.B., SIMPSON, G.L., SOLYMOS, P., STEVENS, M.H.H., SZOECS, E. and WAGNER, H., 2019 [viewed 1 October 2019]. Package "Vegan" [online]. CRAN. Available from: https://cran.r-project.org/web/packages/ vegan/vegan.pdf

OYANEDEL, A., VALDOVINOS, C., AZOCAR, M., MOYA, C., MANCILLA, G., PEDREROS, P. and FIGUEROA, R., 2008. Patrones de distribución espacial de los macroinvertebrados bentónicos de la cuenca del río Aysen (Patagonia Chilena). Gayana (Concepción), vol. 72, no. 2, pp. 241-257. http://dx.doi.org/10.4067/S071765382008000200011.

R DEVELOPMENT CORE TEAM, 2009. $R$ : a language and environment for statistical computing. Vienna, Austria: R Foundation for Statistical Computing.

RIVERA, N.R., ENCINA, F., MUÑOZ-PEDREROS, A. and MEJIAS, P., 2004. La calidad de las aguas en los ríos Cautín e Imperial, IX región, Chile. Información Tecnológica, vol. 15, no. 5, pp. 89-101. http://dx.doi.org/10.4067/S071807642004000500013 . 
SANTIAGO, C.M., RAGGI, J.P.F. and ERICES, L.V., 2016. Urban growth trends in midsize Chilean cities: the case of Temuco. Urbe, vol. 8, no. 3, pp. 375-389. http://dx.doi.org/10.1590/21753369.008.003.AO07.

SCHEIBLER, E.E., ROIG-JUÑENT, S.A. and CLAPS, M.C., 2014 Chironomid (Insecta: Diptera) assemblages along an Andean altitudinal gradient. Aquatic Biology, vol. 20, no. 2, pp. 169-184. http://dx.doi.org/10.3354/ab00554.

VARGAS, P.V., ARISMENDI, I., LARA, G., MILLAR, J. and PEREDO, S., 2010. Evidencia de solapamiento de micro-habitat entre juveniles de salmón introducido Oncorhynchus tshawytscha y el pez nativo Trichomicterus aerolatus en el río Allipén, Chile. Revista de Biología Marina y Oceanografía, vol. 45, no. 2, pp. 285-292. http://dx.doi.org/10.4067/S071819572010000200010.

VEGA, R., RÍOS, P.L., ENCINA, F., NORAMBUENA, J.A., BARILE, J. and MARDONES, A., 2020. First reports of inventory and role of macroinvertebrate and fish in Cautín River $\left(38^{\circ} \mathrm{S}\right.$, Araucania region, Chile). Brazilian Journal of Biology $=$ Revista Brasileira de Biologia, vol. 80, no. 1, pp. 215-228. http://dx.doi. org/10.1590/1519-6984.203511. PMid:31066767.

ZAR,J.H., 1999. Biostatistical analysis. New Jersey: Prentice Hall, Inc., 661 p. 